\title{
PENGEMBANGAN MODEL PEMBELAJARAN PROGRAM PRODUKTIF SMK UNTUK MEMBENTUK KARAKTER KEWIRAUSAHAAN LULUSAN
}

\author{
Samsudi \\ Fakultas Ilmu Pendidikan Universitas Negeri Semarang \\ email: samsudi234@staff.unnes.ac.id
}

\begin{abstract}
Abstrak: Pembelajaran program produktif SMK memiliki posisi strategis dalam pengembangan kompetensi siswa, baik kompetensi teknis (hard competence) maupun kecakapan kewirausahaan (soft competence). Penelitian ini bertujuan untuk menemukan model pembelajaran program produktif SMK mencakup materi ajar, metode pembelajaran, dan evaluasi hasil belajar yang dapat mengembangkan karakter kewirausahaan lulusan. Hasil penerapan pendekatan research and development, pada bidang keahlian Teknologi dan Rekayasa, Pariwisata, serta Bisnis dan Manajemen dapat dikembangkan model pembelajaran program produktif SMK yang mencakup tiga aspek, yakni materi pembelajaran, metode pembelajaran, dan evaluasi hasil pembelajaran produktif. Materi pembelajaran perlu didesain dengan memfokuskan pada kegiatan produktif (membuat atau menciptakan produk baik barang maupun jasa) yang menekankan karakter kewirausahaan, metode pembelajaran bersifat penugasan atau project-work, dan evaluasi hasil pembelajaran perlu menerapkan teknik evaluasi unjuk kerja dengan menekankan evaluasi proses dan produk.
\end{abstract}

Kata Kunci: model pembelajaran, program produktif SMK, karakter kewirausahaan

\section{THE DEVELOPMENT OF THE PRODUCTIVE TEACHING MODEL TO BUILD THE ENTREPRENURSHIP CHARACTER OF VOCATIONAL HIGH SCHOOL GRADUATES}

\begin{abstract}
The vocational school productive program teaching had a strategic position in the development of students' competences, both the hard competence and the soft competence. This study was aimed to find the vocational school productive teaching model involving teaching materials, teaching methods, and learning achievement evaluation which could develop the entrepreneurship character of the graduates. Through the implementation of the research and development approach in the skill area of technology and engineering, tourism, and business and management, a vocational school productive teaching model was developed involving three aspects, that is, teaching materials, teaching methods, and productive learning achievement evaluation. The teaching materials should be designed by focusing on the productive activities (creating the products in the form of both goods and services) which emphasized the entrepreneurship character; the teaching methods were in the form of providing tasks or project-work, and the learning achievement evaluation needed to use the performance evaluation emphasizing the process and product evaluation.
\end{abstract}

Keywords: the teaching model, SMK productive program, entrepreneurship character

\section{PENDAHULUAN}

Pada proses penyelenggaraan pembelajaran di SMK dikenal adanya pembelajaran program produktif. Pembelajaran ini berisi sekumpulan mata pelajaran (diklat) yang secara spesifik bertujuan membekali peserta didik agar memiliki kompetensi produktif melalui pembelajaran praktik di sekolah dan/atau di dunia usaha/industri, sesuai dengan Standar Kompetensi Kerja Nasional Indonesia (SKKNI).
Posisi strategis pembelajaran program produktif SMK, pada dasarnya merupakan bench mark yang mestinya menjadi acuan kualitas dalam penyelenggaraan pendidikan di SMK. Namun demikian dalam kenyatannya belum dimanfaatkan secara optimal khususnya untuk pengembangan karakter dan jiwa kewirausahaan lulusan SMK.

Pembelajaran program produktif di SMK masih lebih banyak berorientasi pada pembekalan dan pencapaian hard competence, yakni 
kompetensi/keterampilan teknis sesuai standar kompetensi kerja (SKKNI). Sementara aspek soft competence, terutama kecakapan kewirausahaan belum dikembangkan secara optimal. Dampak yang muncul kemudian adalah kecenderungan meningkatnya pencari kerja (job seeker) lulusan SMK dari tahun ke tahun. Sementara jumlah lulusan yang terus meningkat setiap tahun, tentu akan semakin memperbesar jumlah pengangguran lulusan. Pada tahun 2006 secara nasional lulusan SMK berjumlah 628.285 orang, tahun 2007 berjumlah 736.981 orang, tahun 2008 berjumlah 925.543 orang. (Depdiknas, 2008). Data Kantor Pusat Statistik DKI melaporkan bahwa pada tahun 2009 lulusan SMK menjadi penyumbang terbesar tenaga pengangguran terbuka (TPT), dengan jumlah 170.232 orang, sementara lulusan SMA 139.754 orang, lulusan Diploma 20.253 orang, lulusan S1 dan S2 30.452 orang. Lulusan SLTA secara nasional masih menempati peringkat tertinggi dalam tenaga pengangguran terbuka (TPT), dan lulusan SMK menjadi penyumbang terbesar. Data pada Agustus 2008 menyajikan, persentase tenaga pengangguran terbuka berdasarkan lulusan pendidikan sbb: (1) SMK: 14,59\%; (2) SMA: $14,50 \%$; (3) Diploma: 13,66\%; dan (4) universitas $13,08 \%$ (Kemnakertrans, 2010).

Belajar dari banyaknya jumlah lulusan SMK yang tidak terserap dalam lapangan kerja (tahun 2007 lulusan SMK yang terserap di lapangan kerja sebesar 385.986 orang dari 628.285 orang lulusan atau sekitar 61,43\%) (Depdiknas, 2008). Jika dikaitkan dengan lapangan kerja yang terbatas, sementara jumlah lulusan yang meningkat tajam setiap tahun, maka pengembangan sikap mental kewirausahaan lulusan SMK memiliki nilai strategis. Hal ini dikarenakan dengan pengembangan karakter dan jiwa kewirausahaan berarti penyelenggaraan pendidikan di SMK tidak hanya difokuskan pada penyiapan lulusan menjadi tenaga kerja dunia usaha/industri, melainkan juga fokus pada pembentukan karakter kewirausahaan lulusan.
Kebutuhan akan pengembangan karakter kewirausahaan sesungguhnya sejalan dengan hasil penelitian di Harvard University Amerika Serikat, yang menyebutkan bahwa ternyata kesuksesan seseorang tidak ditentukan sematamata oleh pengetahuan dan keterampilan teknis (hard skill) saja, tetapi lebih oleh kemampuan mengelola diri dan orang lain (soft skill). Penelitian ini mengungkapkan, kesuksesan seseorang hanya ditentukan sekitar $20 \%$ oleh hard skill dan sisanya $80 \%$ oleh soft skill (Kemendiknas, 2010:1).

Urusan mencari kerja lulusan SMK menjadi fenomena yang mencolok dan patut pendapatkan perhatian serius. Kepala sekolah, guru, orang tua, dan siswa sendiri mengakui, bahwa sekolah di SMK memang menjadi tumpuan untuk memperoleh pekerjaan. Data tentang hal tersebut disajikan dalam Tabel 1.

Dalam penelitian Winarno (2009) disimpulkan bahwa materi ajar dan strategi pembelajaran kewirausahaan yang diberikan di SMK saat ini tidak cukup efektif dalam mengembangkan nilai-nilai kewirausahaan siswa. Demikian pula pemahaman dan pengalaman kewirausahaan para pengelola (wali kelas, guru dan pembimbing) ternyata belum sepenuhnya mendukung pencapaian tujuan pengembangan karakter kewirausahaan.

Pengembangkan nilai-nilai kewirausahaan utamanya di SMK memerlukan pendekatan yang tepat dalam pendidikan dan pelatihan (diklat), baik pendidikan di sekolah maupun praktik kerja di dunia usaha/industri.

Pengembangan materi ajar, metode pembelajaran, dan sistem penilaian hasil belajar yang fokus mengacu kepada indikator karakter kewirausahaan pada pembelajaran program produktif pada dasarnya dapat mengembangkan dan membentuk kompetensi dan karakter kewirausahaan lulusan.

Atas uraian latar belakang pada pendahuluan, maka tujuan penelitian ini dijabarkan sebagai berikut. Pertama, mendeskripsikan kebutuhan pengembangan model pembelajaran program produktif dalam rangka membentuk 
Tabel 1. Fenomena Lulusan SMK yang Mencari Kerja (\%)

\begin{tabular}{llll}
\hline \multicolumn{1}{c}{ Kepala SMK } & \multicolumn{1}{c}{ Guru SMK } & \multicolumn{1}{c}{ Orang tua siswa } & \multicolumn{1}{c}{ Siswa SMK } \\
\hline 70,59\% mengakui & 100\% mengakui & $\bullet$ 67,64\% menyatakan lulusan & $\bullet 71,88 \%$ menyatakan bahwa \\
bahwa lulusan & bahwa lulusan SMK & SMK masih berorientasi & setelah lulus SMK akan \\
SMK masih & masih berorientasi & mencari pekerjaan/menjadi & mencari pekerjaan/menjadi \\
berorientasi & mencari & karyawan. & karyawan. \\
mencari & pekerjaan/menjadi & $\bullet 82,35 \%$ menyatakan yakin & $\bullet 100 \%$ yakin setelah lulus \\
pekerjaan/menjadi & karyawan. & anaknya akan mendapatkan & akan mudah memperoleh \\
karyawan. & & pekerjaan setelah lulus & pekerjaan \\
& & SMK & $\bullet 84,37 \%$ menyatakan adalah \\
& & 60,00\% menyatakan adalah & sebuah masalah jika setelah \\
& & sebuah masalah jika anak- & lulus SMK tidak \\
& & nya setelah lulus SMK ti- & memperoleh pekerjaan \\
& & dak memperoleh pekerjaan & \\
\hline
\end{tabular}

kewirausahaan lulusan. Kedua, menemukan desain model pembelajaran yang mengintegrasikan materi ajar, metoda pembelajaran, dan evaluasi hasil pembelajaran program produktif SMK untuk membentuk karakter kewirausahaan lulusan.

\section{METODE}

Desain yang diterapkan dalam penelitian ini adalah penelitian dan pengembangan (research and development) (Borg \& Gall, 1993: 773).

Lokasi penelitian ini di kota Semarang, dengan subjek penelitian ditetapkan secara purposive, yakni SMK bidang keahlian teknologi dan rekayasa, bisnis dan menejemen, serta bidang pariwisata. Pada setiap SMK diambil satu kompetensi keahlian untuk dikembangkan materi ajar, metode pembelajaran, dan sistem evaluasi dengan mengacu kepada indikator karakter kewirausahaan.

Studi pendahuluan dilaksana-kan dengan menggunakan teknik angket dan kajian literatur (literature review). Pada tahap pengembangan digunakan teknik FGD, dengan teknik pengumpulan data yang pokok adalah angket. Pada tahap ujicoba model, teknik pengumpulan data yang digunakan adalah penilaian hasil penerapan model terhadap pembentukan karakter kewirausahaan lulusan.

Instrumen pengumpulan data yang digunakan dalam penelitian ini adalah: (1) angket (daftar pertanyaan) digunakan untuk mengum- pulkan data pada tahap studi pendahuluan dan pengembangan; (2) angket (skala penilaian) digunakan untuk menilai hasil penerapan model terhadap pembentukan karakter kewirausahaan lulusan.

Studi pendahuluan dilaksanakan secara deskriptif-analitis, untuk mendeskripsikan dan analisis tentang model faktual pembelajaran program produktif, utamanya materi ajar, metode pembelajaran, dan evaluasi, dalam membentuk karakter kewirausahaan. Atas dasar temuan tersebut, peneliti merumuskan model pengembangan.

Langkah-langkah pengembangan dan validasi model dilaksanakan untuk mendeskripsikan keterlaksanaan model serta menilai hasil penerapan model terhadap pembentukan kewirausahaan lulusan.

Teknik analisis pada tahap studi pendahuluan adalah, temuan atau fakta-fakta model pembelajaran program produktif dideskripsikan dalam bentuk sajian data (mean, median, modus $\mathrm{dsb}$ ), kemudian dianalisis (diinterpretasikan) secara deskriptif-analitis.

Tahap pengembangan dan validasi model menggunakan pendekatan analisis deskriptif dalam bentuk sajian data; demikian juga dalam ukuran keterterapan model (applicability) dan hasil penerapan model dianalisis secara deskriptif-analitis. Bagan alur penelitian dan pengembangan ini ditunjukkan pada Gambar 1. 


\section{HASIL DAN PEMBAHASAN}

Hasil studi pendahuluan ada dua, yakni (1) analisis kebutuhan tentang pengembangan model pembelajaran produktif SMK untuk membentuk karakter kewirausahaan lulusan SMK; dan (2) deskripsi model faktual penyelenggaraan progran program produktif SMK.

\section{Hasil Analisis Kebutuhan}

Hasil analisis kebutuhan diperoleh dari dua kelompok sumber data (responden), yakni sumber daya manusia dan jenis SMK. Analisis kebutuhan dari kelompok sumber daya manusia melibatkan responden kepala sekolah SMK, guru, instruktur Du/Di. Analisis kebutuhan melalui jenis SMK, melibatkan SMK pada program keahlian bisnis dan manajemen, pariwisata, dan teknologi. Variabel yang menjadi fokus pengembangan model meliputi: materi pembe- lajaran, metode pembelajaran, dan evaluasi hasil pembelajaran.

Temuan dideskripsikan dalam bentuk sajian data (mean, median, modus), kemudian dianalisis (diinterpretasikan) secara deskriptifanalitis. Data yang telah diolah dapat dilihat pada Tabel 1 dan Gambar 2.

Mengacu kepada konsep skala Likert, arti rentang skor adalah sebagai berikut: $(0,00 \mathrm{s.d}$ 10,00) sangat dibutuhkan; (11,00 s.d 20,00) dibutuhkan; (21,00 s.d 30,00) tidak dibutuhkan; dan $(31,00$ s.d 40,00) sangat tidak dibutuhkan. Atas dasar hal tersebut, maka Tabel 1 dan Gambar 2 di atas memiliki arti bahwa guru, kepala sekolah, dan instruktur Du/Di secara umum mengatakan bahwa pada aspek materi, metoda, evaluasi pembelajaran program produktif dibutuhkan pengembangan untuk membentuk kewirausahaan lulusan.

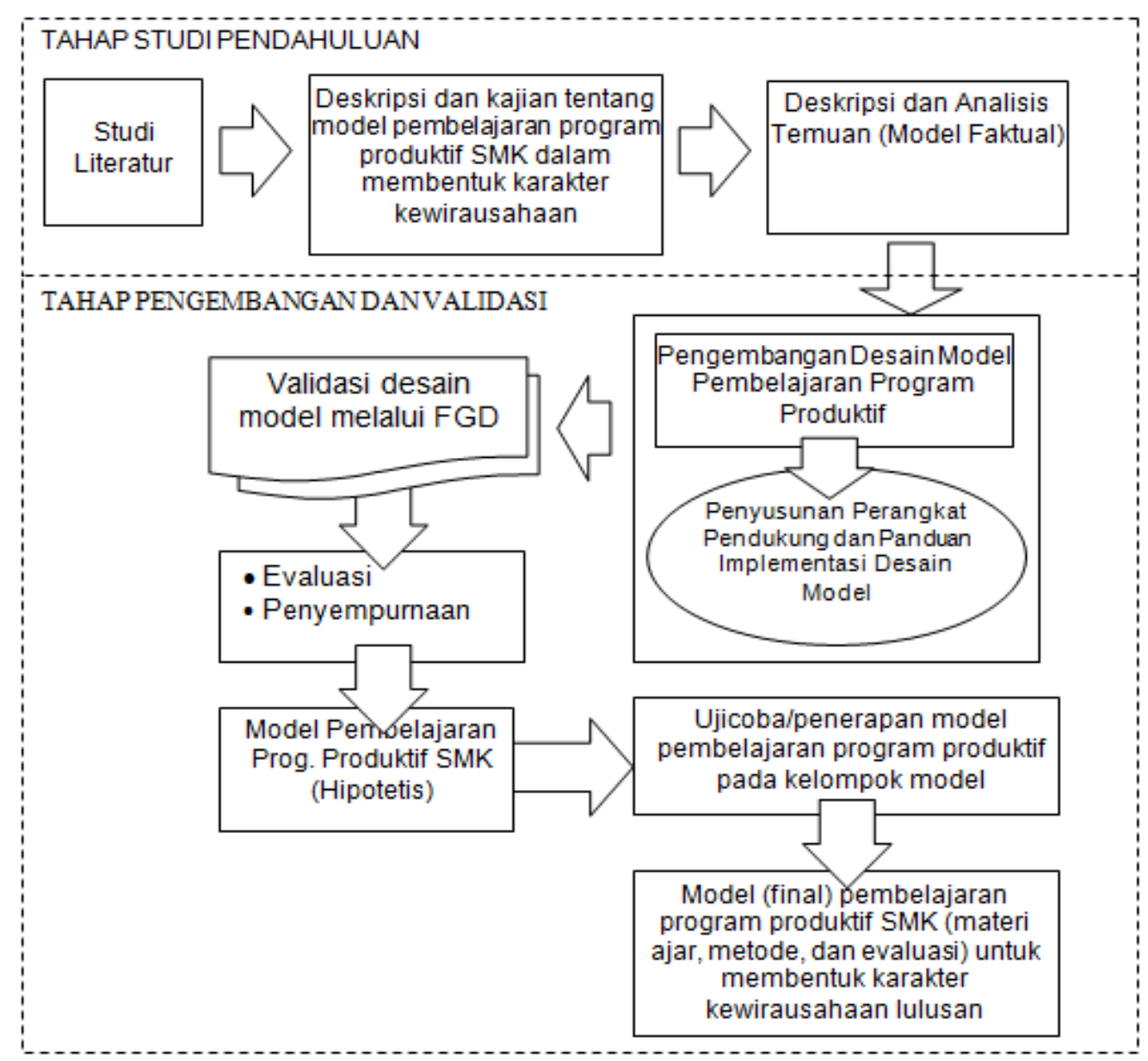

Gambar 1. Diagram Alir Proses Penelitian Pengembangan Model Pembelajaran Produktif untuk Membentuk Karakter Kewirausahaan Lulusan 
Tabel 1. Data Responden Berdasar Sumber Daya Manusia

\begin{tabular}{llll}
\hline Sumberdaya & Materi & Metoda & Evaluasi \\
\hline Guru & 19.69 & 17.14 & 19.03 \\
Kepala Sekolah & 21.14 & 17.71 & 18.43 \\
Instruktur & 18.54 & 16.08 & 18.23 \\
\hline
\end{tabular}



Gambar 2. Grafik Analisis Kebutuhan Pengembangan Model Berdasar SDM

\section{Tabel 2. Data Responden Berdasar Jenis} SMK

\begin{tabular}{llll}
\hline Jenis SMK & Materi & Metode & Evaluasi \\
\hline Bisnis & 16.71 & 13.86 & 16.86 \\
Pariwisata & 19.71 & 17.02 & 18.88 \\
Teknologi & 22.17 & 20.17 & 20.17 \\
\hline
\end{tabular}

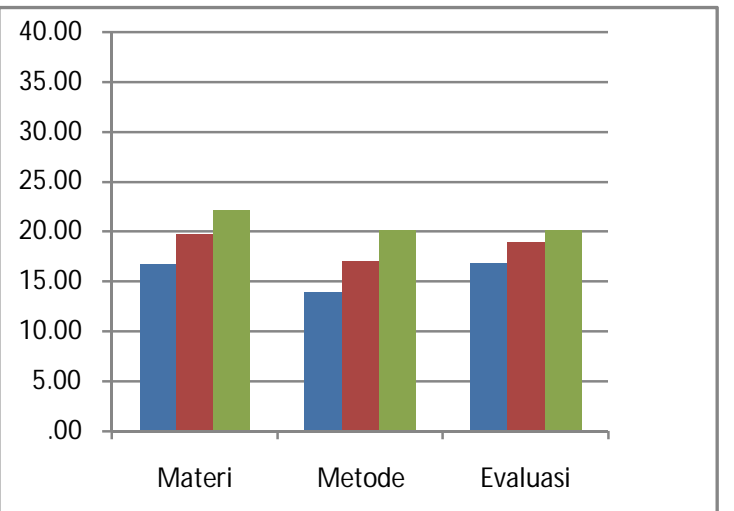

Gambar 3. Grafik Analisis Kebutuhan Pengembangan Model Berdasarkan Bidang Keahlian SMK
Tabel 2 dan Gambar 3 di atas menunjukkan bahwa kelompok SMK Bisnis dan Pariwisata menganggap aspek materi, metoda, evaluasi pembelajaran program produktif dibutuhkan pengembangan untuk membentuk kewirausahaan lulusan. Pada kelompok SMK Teknologi menganggap kurang perlu pengembangan.

\section{Model(Faktual) Pembelajaran Program Pro- duktif}

Atas hasil pengumpulan data dari responden (kepala sekolah, guru produktif, dan instruktur Du/Di) baik pada SMK Bidang Teknologi dan Rekayasa, Bisnis dan Manajemen, maupun Pariwisata, dapat dideskripsikan bahwa: (1) materi pembelajaran produktif selama ini lebih berisi keterampilan teknis (produktif) dengan menekankan pembuatan/penciptaan produk atau jasa, akan tetapi tidak dikaitkan dengan pengembangan karakter kewirausahaan; (2) metoda pembelajaran produktif yang lebih banyak dipilih guru adalah ceramah dan penugasan; (3) penilaian hasil belajar program produktif kurang menekankan penilaian proses, dan lebih banyak menekankan penilaian hasil (produk).

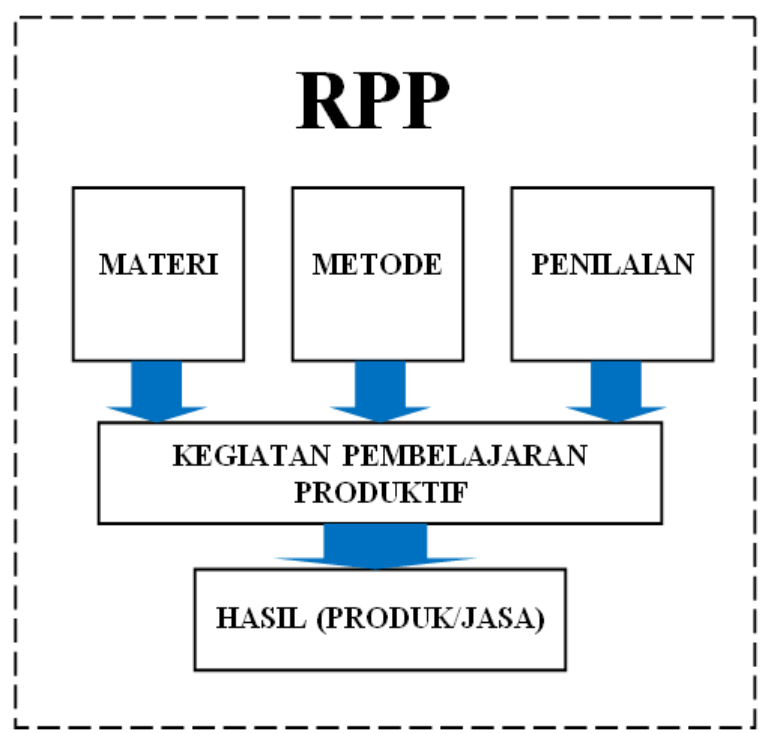

Gambar 4. Bagan Model Faktual Pembelajaran Program Produktif SMK

Fakta yang terjadi, materi, metoda, dan penilaian hasil pembelajaran program produktif 
dilaksanakan tidak dalam satu kesatuan yang utuh sehingga tidak dapat membentuk dan mengembangkan kecakapan kewirausahaan. Hasil pelaksanaan pembelajaran program produktif juga tidak dapat digunakan untuk menilai dan mengukur pengembangan kecakapan kewirausahaan.

\section{Desain Hasil Pengembangan Model Pembe- lajaran Produktif}

Atas hasil analisis kebutuhan dan deskripsi temuan model faktual, desain pengembangan difokuskan pada tiga aspek secara terintegratif sebagai berikut. (1) Pengembangan materi pembelajaran difokuskan pada kegiatan teknis (produktif) dengan menekankan pembuatan/penciptaan barang atau jasa, namun sekaligus dikaitkan dengan pengembangan karakter kewirausahaan. (2) Metode pembelajaran menekankan penugasan dan/atau project-work. (3) Penilaian menerapan teknik penilaian unjuk kerja dengan menekankan proses dan hasil (produk) pembelajaran. Secara bagan, model pengembangan disajikan pada Gambar 5.

Model pengembangan ini diterapkan oleh guru sejak penyusunan rencana pelaksanaan pembelajaran (RPP) dengan menyelaraskan antara materi, metoda dan penilaian sebagai komponen utama dalam skenario pembelajaran yang mengandung muatan kewirausahaan. Materi dirancang berbasis pembuatan/penciptaan produk atau jasa dengan tekanan karakter kewirausahaan; metoda didesain dengan penugasan dan/atau project-work, sedangkan penilaian didesain dengan teknik unjuk kerja yang menekankan penilaian proses dan produk. Desain pada tiga komponen utama (materi, metoda, dan penilaian) tersebut diimplementasikan dalam kegiatan pembelajaran, untuk selanjutkan akan memperoleh hasil belajar (siswa) yang memiliki kompetensi teknis (produktif) dan kewirausahaan. Desain pengembangan ini dapat diterapkan pada SMK bidang keahlian Tekonologi dan Rekayasa, Bisnis dan Manajemen, serta Pariwisata.

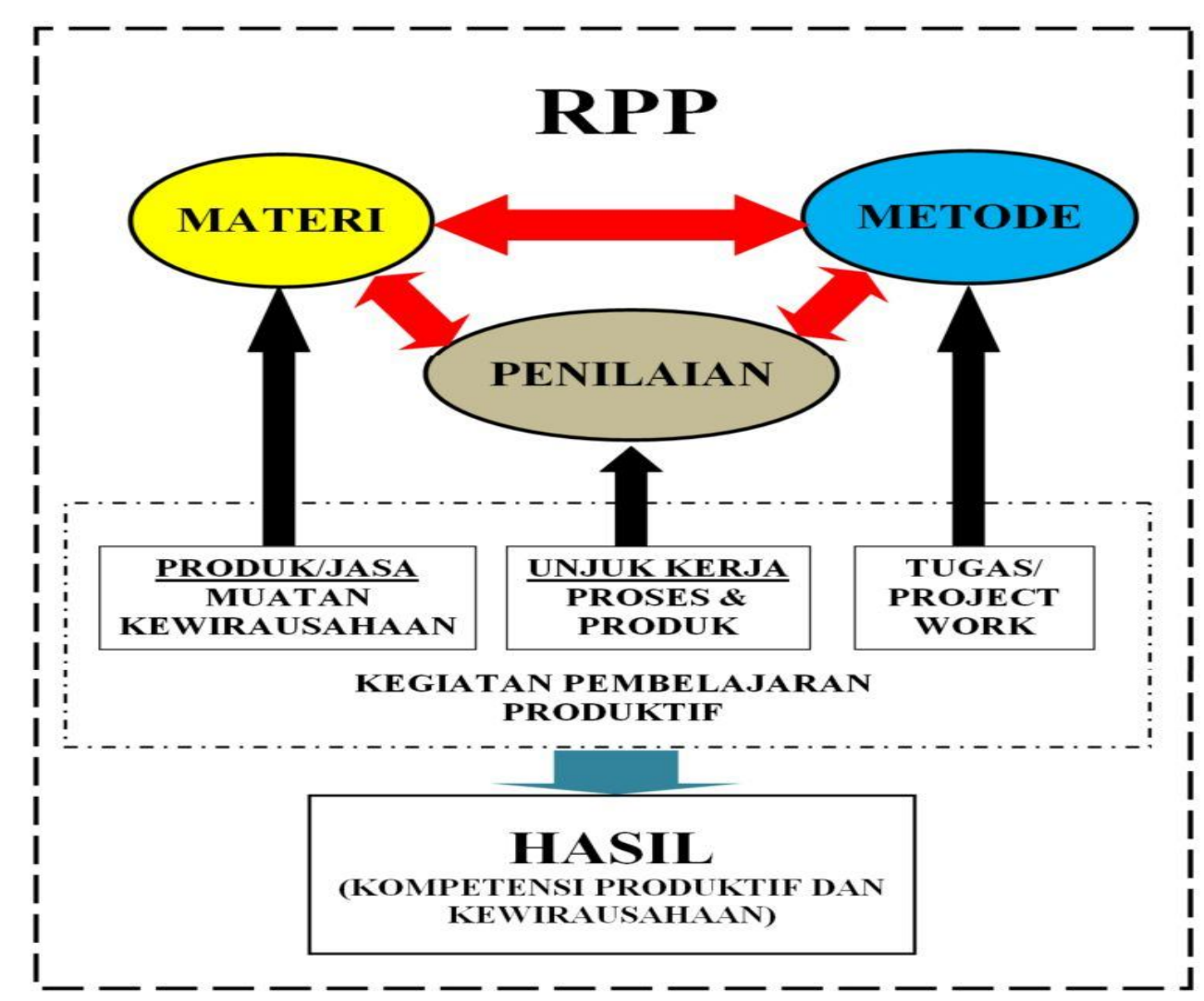

Gambar 5. Bagan Model Pengembangan Pembelajaran Program Produktif untuk Membentuk Karakter Kewirusahaan Lulusan 


\section{Pembahasan}

Beberapa konsep pendekatan pembelajaran memiliki keselarasan dalam pembentukan karakter kewirausahaan sehingga dapat diimplementasikan dalam pembelajaran program produktif SMK. Sudarmiatin (2009:110) menjelaskan beberapa pendekatan yang sesuai dalam pembelajaran kewirausahaan di SMK, yakni: (1) pembelajaran berbasis masalah (problem based lerning); (2) pembelajaran berbasis proyek/tugas (project based learning); (3) pembelajaran berbasis kerja (work based learning); dan (4) pembelajaran berbasis jasa layanan (service learning).

Pelaksanaann beberapa pendekatan pendidikan dan pelatihan tersebut dapat berdiri sendiri, ataupun terintegrasi antara beberapa pendekatan. Namun yang esensial adalah pengembangan kewirausahaan bagi siswa SMK diharapkan dapat memberikan sumbangan terhadap beberapa hal antara lain: (1) peningkatan kompetensi lulusan; (2) penajaman kompetensi produktif melalui pengembangan keterampilan kewirausahaan sesuai bidang keahliannya; (3) kemampuan meraih dan menciptakan peluang atas dasar informasi yang diperoleh; (4) kebiasaan untuk bekerja mandiri dan penuh inisiatif; (5) memiliki sikap kreatif dan inovatif dalam menghadapi perubahan (Depdiknas, 2008:3).

Pembelajaran program produktif pada dasarnya bersifat dual-based yakni pembelajaran di sekolah, dan penguatan di dunia usaha/ industri, utamanya dalam mengembangkan kompetensi produktif. Lee (2008) menjelaskan bahwa pembelajaran kejuruan akan efektif mengembangkan kompetensi kerja dan kewirausahaan jika dilaksanakan secara kolaboratif antara sekolah dengan dunia usaha/industri.

Atas dasar temuan penelitian, aspek yang perlu mendapatkan pengembangan dalam pembelajaran program produktif adalah materi pembelajaran, metode, dan penilaian. Ketiga aspek tersebut merupakan komponen utama dalam kurikulum. Dengan demikian, faktor kurikulum menjadi hal penting dalam pengembangan pembelajaran untuk membentuk kemampuan kerja, dan karir lulusan. Seperti dijelaskan Smith
(2007), pembentukan kemampuan kerja dan karir lulusan harus didesain dalam kurikulum sekolah. Sejalan dengan ini, maka pengembangan materi, metode, dan penilaian dalam pembelajaran program produktif akan memperkuat pengembangan kemampuan kerja dan karir lulusan.

Kemampuan guru dan instruktur pendidikan kejuruan juga mendapat perhatian penting. Mndebele (2006), menganggap kemampuan guru dan instruktur pendidikan kejuruan sebagai sesuatu yang penting dalam pengembangan kewirausahaan lulusan. Sejalan dengan temuan penelitian ini, kemampuan guru dan instruktur dalam mendesain pembelajaran/diklat akan meningkatkan kualitas materi, metode dan penilaian hasil pembelajaran program produktif.

\section{PENUTUP}

Berdasarkan hasil penelitian di atas, dapat diambil beberapa kesimpulkan sebagai berikut. Pertama, kebutuhan pengembangan model pembelajaran program produktif SMK untuk membentuk kewirausahaan lulusan dianggap penting oleh kepala sekolah, guru produktif, dan instruktur Du/Di utamanya pengembangan dalam aspek materi pembelajaran, metoda pembelajaran, dan evaluasi hasil pembelajaran.

Kedua, model pembelajaran program produktif SMK yang dilaksanakan saat ini dideskripsikan sebagai berikut. (1) Materi pembelajaran produktif lebih berisi keterampilan teknis (produktif) dengan menekankan pembuatan/ penciptaan produk atau jasa, akan tetapi tidak dikaitkan dengan pengembangan karakter kewirausahaan. (2) Metoda pembelajaran produktif yang lebih banyak dipilih guru adalah ceramah dan penugasan. (3) Penilaian hasil belajar program produktif kurang menekankan penilaian proses, dan lebih banyak menekankan penilaian hasil (produk).

Ketiga, dihasilkan desain model pembelajaran program produktif yang dilaksanakan dalam satu kesatuan yang utuh untuk mengembangkan kecakapan kewirausahaan, sebagai berikut. (1) Pengembangan materi pembelajaran difokuskan pada kegiatan teknis (produktif) 
dengan menekankan pembuatan/penciptaan barang atau jasa, namun sekaligus dikaitkan dengan pengembangan karakter kewirausahaan melalui perumusan indikator pencapaian hasil belajar. (2) Metoda pembelajaran menekankan penugasan dan/atau project-work, yakni mengarahkan peserta didik pada prosedur kerja yang sistematis dan standar untuk membuat atau menyelesaikan suatu produk (barang atau jasa), melalui proses produksi/pekerjaan yang sesungguhnya. (3) Penilaian menerapan teknik penilaian unjuk kerja dengan menekankan proses dan hasil (produk) pembelajaran, yakni mengamati kegiatan peserta didik dalam melakukan sesuatu sejak dari perencanaan, pelaksanaan pembelajaran, pengumpulan data, pengorganisasian, pengolahan dan penyajian data.

\section{UCAPAN TERIMA KASIH}

Ucapan terima kasih disampaikan kepada semua pihak yang membantu terlaksananya penelitian ini khususnya para responden di SMK.

\section{DAFTAR PUSTAKA}

Borg, Walter R. and Gall, Meredith D. 1993. Educational Research: An Introduction. New York and London; Longman.

Depdiknas. 2008. Proyeksi Keterserap-an Lulusan SMK Berdasarkan Bidang Keahlian. Jakarta: Direktorat Pembinaan SMK, Ditjen Manajemen Dikdasmen.

Kemnakertrans. 2010. Prospek Ketenagakerjaan di Indonesia. Jakarta: Makalah dalam Kuliah Umum di Universitas Islam Indonesia.
Kemendiknas. 2010. Pengembangan Pendidikan Kewirausahaan. (Bahan Bimtek Pengembangan Kewirausahaan). Jakarta: Pusat Kurikulum dan Perbukuan. Kemendiknas.

Lee, Jeongwoo. 2008. "Partnerships with Industry for Efficient and Effective Implementation of TVET". International Journal of Vocational Education and Training. Volume 17, Number 2.

Mndebele, Comfort B.S. 2006. "Vocational Entrepreneurship Education in a Developing Country: Self Reported Performance of Male and Female Vocational Instructors in Swziland". International Journal of Vocational Education and Training. Volume 14, Number 1.

Smith, Bettye P. 2007. "Employability Standards: Inclusion in Family and Career Science Middle School Curriculum". Journal of Career and Technical Education. Vol.23, No.1, Fall 2007.

Sudarmiatin. 2009. "Entreprenuership dan Metode Pembelajarannya di SMK". Jurnal Ekonomi Bisnis, Tahun 14 Nomor 2, Juli 2009.

Winarno, Agung. 2009. "Pengembangan Model Pembelajaran Internalisasi Nilai-nilai Kewirausahaan pada SMK di Kota Malang". Jurnal Ekonomi Bisnis, Tahun 14, Nomor 2, Juli 2009. 